\title{
RevistAleph
}

\section{AO MEU MESTRE PROF JORGE NAJJAR}

Solange Santiago Ferreira ${ }^{85}$

Voa meu querido, voa! Sua jornada aqui foi incrível! Te conheci em encontros de formação pela Fundação Municipal de Niterói, em um curso de especialização que fiz no mestrado e, posteriormente, em 2013, fui selecionada para o doutorado na UFF.

Minha querida orientadora Profa Célia Linhares, por motivos pessoais, após quatro semestres do curso, não pôde dar continuidade às orientações de seus doutorandos naquele momento. Perguntei se você poderia me acolher e, de braços abertos, o fez. Mudamos naturalmente, a direção da pesquisa. Com prazo expirando para a qualificação, você me deu metas, conheceu minha trajetória de vida, minhas incertezas, inseguranças, limites pessoais e acadêmicos, me ouviu com a sensibilidade que Ihe era própria, um dom! Sempre afirmou que eu poderia, que eu conseguiria, que eu já teria tudo, só faltava escrever. Qualifiquei, prossegui.

Sempre me incentivou a participar dos seminários, congressos dentro e fora do país, voei alto junto com você, para Paris, Peru, de norte a sul no Brasil e por aí... Cumpria o papel de pai, de professor, puxava a orelha, exigia mais: escrever, apresentar trabalhos, junto com o grupo de pesquisa sob sua coordenação, o NUGEPPE, onde união era o que valia!

Ao final do curso, novamente bateu aquele pânico em mim. Aquele que advindo do que a sociedade impõe e que eu sentia desde a infância: quem vem de escola pública não pode, tem formação precária; quem se origina de comunidades menos favorecidas, não consegue; só os melhores nascidos em berço de ouro chegam lá. Você me ajudou a acreditar que não, que eu poderia ser mais e que estava pronta! Hoje sou Professora Doutora, com muito orgulho, orientada por Jorge Nassin Vieira Najjar, o Grande Tubarão Branco da Academia, da minha vida! Voou ontem levando

\footnotetext{
85 Doutora e mestre em Educação (UFF). Especialista em Supervisão, Orientação e Administração Escolar (UFF) e Licenciada em Pedagogia (UERJ). Coordenadora do Núcleo de Estágio (NEST), da Fundação Municipal de Educação de Niterói/RJ.
} 


\section{RevistAleph}

nosso amor, deixando igualmente o seu.

Sou privilegiada! Tenho uma parte de você em mim, principalmente a que continua me dizendo que posso mais! Sou grata! Agora você vai continuar brilhando por aí, em outra dimensão, deixando um rastro de esperança e alegria para todos nós. Certamente, nos encontraremos de novo e terei muitas histórias para te contar. Como já virou estrela, a gente fica por aqui com a saudade desse sorriso largo e generoso. Um amor sem fim que nos fortalece a cada dia. Uma pipoca e uma empadinha de doce de leite para você, meu querido! Segura aí um beijo enorme dessa sua amiga. Você foi e sempre será "o cara".
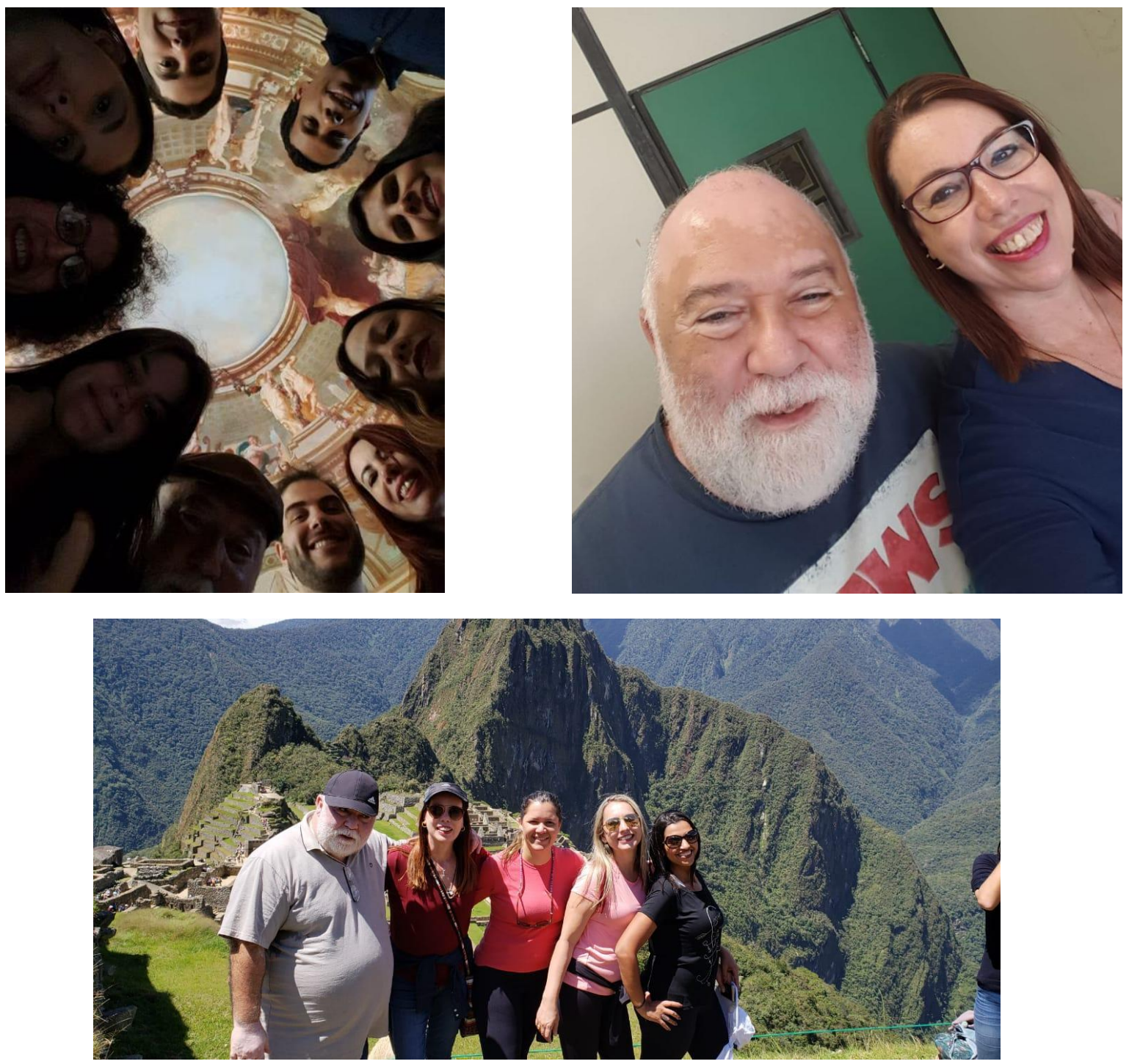

Fonte: Arquivo pessoal da autora. 